\title{
С.Б. Белоглазова
}

\section{РЕФОРМА ВЕДОМСТВЕННЫХ ШКОЛ НА КИТАЙСКО-ВОСТОЧНОЙ ЖЕЛЕЗНОЙ ДОРОГЕ ВО ВТОРОЙ ПОЛОВИНЕ 1920-х ГГ.}

\begin{abstract}
Статья посвящена слабо изученной в отечественной историографии проблеме советской реформы образования на Китайско-Восточной железной дороге. Изучены политика советской администрации КВЖД по отношению к системе подведомственных ей учебных заведений и основные направления проведённой ею образовательной реформы. Прослежены динамика и трансформация сети железнодорожных школ с учетом специфической политической ситуации в Маньчжурии и переходом ведомственных школ под управление китайской администрации. В научный оборот введены новые материалы из ведомственных изданий.

Ключевые слова: Китай; Маньчжурия; СССР; КВЖД; образовательная политика; реформа школы.
\end{abstract}

Образование является важным фактором формирования национально-культурной и гражданской идентичности, основным источником социализации личности и развития человеческого капитала. Всё это определяет социальную значимость исследований по проблеме реформирования образовательных систем и стимулирует интерес отечественных историков к проблеме образовательных реформ в России. Набирающая силу ретроспективная рефлексия по поводу итогов современной реформы образования усиливает интерес общественности, экспертов, педагогов и части современной политической элиты к переосмыслению исторического феномена советской школы, актуализирует на современном переломном этапе развития российского общества обращение к историческому опыту реформ национальной системы образования.

Система русского образования, созданная на линии КВЖД в Маньчжурии, являлась частью функционировавшего в инокультурной и иноэтнической среде образовательного пространства Российской империи. В рассматриваемый период оно утратило гомогенность, расколовшись на эмигрантские и советские школы. В отечественной историографии к изучению истории русских школ в ближнем зарубежье обратились на рубеже 1980-1990-х гг. Сложившаяся с тех пор исследовательская традиция представляет историю русских учебных заведений в Маньчжурии как составную часть истории восточной ветви российской эмиграции. При этом фокус таких исследований сосредоточивается на эмигрантских школах, которые позицируются авторами как хранители и трансляторы национально-культурной идентичности русских эмигрантов. Советский сегмент системы образования на КВЖД долгое время оставался за пределами внимания исследователей, видимо, потому, что не отвечал идеологическим запросам постсоветского общества. В последнее десятилетие появились исследования по истории русских школ в Маньчжурии, авторы которых обратились, в том числе, и к истории советских школ. Вместе с тем история советской реформы школы на КВЖД занимает в общем объеме таких работ довольно скромное место и ещё не стала предметом специального изучения. Показательными в этом отношении являются труды О.И. Еропкиной [1], О.А. Косиновой [2], И.В. Потаповой [3. С. 78-81, 8387], китайской исследовательницы Че Чуньинь [4. C. 21-23] и коллективная монография, посвященная этнокультурным и социально-экономическим проблемам освоения смежных территорий СевероВосточной Азии в XVII - первой половине XX в., включающая раздел по истории русских школ в Маньчжурии [5. С. 239-242].

Целью данной статьи является исследование процесса советской школьной реформы на КВЖД. В рамках поставленной цели определены следующие задачи: проанализировать комплекс мер советской администрации КВЖД по реформированию сети ведомственных школ, определить структуру и принципы организации новой школы, показать специфику учебно-воспитательного процесса и организационной жизни в советских учебных заведениях, раскрыть политику советской и китайской администрации по отношению к ведомственным школам, влияние политико-правовой среды и политической конъюнктуры на динамику школьного строительства в связи с переходом ведомственных школ под китайское управление. Также делается попытка привлечь внимание исследователей к необходимости пересмотра сохраняющейся в отечественной историографии традиции методологического разрыва в изучении истории образования досоветского и советского периодов. По нашему убеждению, истоки реализованной в 1920-е гг. в СССР советской реформы образования начинаются с проекта реформы 1915-1916 гг. министра народного просвещения графа П.Н. Игнатьева и программы социо-педагогических преобразований 1917 г., подготовленной Государственным Комитетом по народному образованию при Временном правительстве. Поэтому, хотя хронологические рамки собственно советской реформы школы на КВЖД включают период от перехода дороги под совместное управление СССР и Китая (октябрь 1924) до военного советско-китайского противостояния 1929 г., для более глубокого раскрытия темы исследования автор считает целесообразным показать исторический контекст, предшествующий советской реформе ведомственных школ.

Основной источниковой базой статьи являются ведомственные издания, выходившие под редакцией Экономического бюро КВЖД: «Экономический Вестник Маньчжурии» (1923-1925), «Вестник Маньчжурии» (1925-1934) и др. Сегмент такого рода источников слабо привлекался исследователями истории образования, так как тематика их посвящалась, главным образом, вопросам экономики Маньчжурии 
и сопредельных с Китаем стран. Тем не менее отдельные издания содержат информационные и статистические обзоры советского школьного строительства на КВЖД, подготовленные, в том числе, и на основе данных Учебного отдела дороги. Извлеченные сведения современны происходившим событиям, зафиксированы лицами, непосредственно причастными к реформе, и поэтому имеют важную информационную ценность для исследователей.

Первые изменения в системе ведомственных школ на линии дороги были связаны с попытками введения новой образовательной модели в России, предпринятыми в период реформы 1915-1916 гг. Суть данной реформы заключалась в унификации национальной системы образования на основе замещения школ разного типа единым типом образовательного учреждения - единой школой в составе I и II ступени, с введением которой все уровни образования становились доступными для всех сословий российского общества [6. С. 4]. До Революции 1917 г. единая школа ни в России, ни в полосе отчуждения КВЖД введена не была. Тем не менее в рамках реформы Игнатьева сеть железнодорожных училищ повышенного типа, соответствовавшая I ступени средней школы и включавшая, по данным руководителя Учебного отдела КВЖД Н.В. Борзова, в 1915/16 учебном году 14 учебных заведений [7. Л. 31-32], к началу 1917 г. расширилась до 22 школ [8. С. 17]. После Февральской революции начались первые опыты по соединению обучения с трудовым воспитанием и введению школьного самоуправления, менявшего старый иерархический принцип управления [Там же. С. 17-18]. 23 сентября 1917 г. Правление КВЖД издало приказ № 353, в соответствии с которым в начальных школах на линии дороги стали заниматься по разработанным министерством П.Н. Игнатьева «Временным программам для начальных школ» [Там же. С. 1-61], принципиально отличавшиеся от действовавших в России с 1897 г. учебных курсов. Традиционная предметная группировка учебного материала заменялась распределением его по четырём комплексам: 1) физика и химия, 2) землеведение, 3) ботаника, 4) зоология [Там же. С. 14-31]. «Закон Божий» позицировался как дисциплина по выбору, и по заявлениям родителей ученики могли быть освобождены от его изучения [Там же. С. 61].

Реформа единой школы касалась только подведомственных КВЖД школ. Школы ведения Харбинского общественного управления и частные учебные заведения продолжали работать в автономном режиме и выдавали аттестаты зрелости на основаниях, действовавших до 1917 г. Именно в таких школах, сохранявших традиционную систему обучения из дореволюционной эпохи, эмигранты предпочитали учить своих детей.

В 1920 г. указом президента Китайской Республики Сюй Шичана для подданных Российской империи отменялось право экстерриториальности; полоса отчуждения КВЖД вошла в состав Особого района Восточных провинций (ОРВП), и на неё распространилась власть китайской администрации. Вслед за этим китайское правительство заявило о своих правах на КВЖД, настояв на «справедливом разделении» руко- водящих должностей между китайцами и русскими. Значение КВЖД не ограничивалось решением задач логистики. Дорога являлась одним из главных факторов развития огромного края, и от неё зависела жизнь русской колонии и китайского населения в Маньчжурии. Вопрос о том, кто будет владеть КВЖД, приобретал принципиальное значение. Приход китайцев в руководящие звенья изменил расстановку сил в правлении КВЖД и позволил администрации ОРВП через своих агентов влиять на систему образования на линии дороги, в частности открывать за счёт бюджета КВЖД и Харбинского муниципалитета китайские учебные заведения. В 1923 г. на средства КВЖД были открыты 2 китайские школы, через год их стало 10 [10. C. 39]. Такую активность можно объяснить тем, что в 1920 г. Министерство народного просвещения Китая приняло решение о введении начального всеобуча, а также правительственным курсом на подготовку национальных кадров специалистов для народного хозяйства Китайской Республики. Ведомственные школы дороги становились основным источником подготовки кадров специалистов из среды местного русского и китайского населения. Соперничество за обладание железной дорогой побуждало русскую администрацию во главе с управляющим КВЖД инженером Б.В. Остроумовым принимать меры, купировавшие политику постепенной «китаизации» КВЖД, в том числе и в сфере образования. С этой целью была активизирована деятельность по расширению сети ведомственных школ.

В 1923 г. в ведение Учебного отдела КВЖД вошли 49 начальных школ (І ступени) и 22 средние (II и III ступени); всего 71 школа, в которых получали образование около 10 тыс. детей [8. С. 20]. В 1921-1923 гг. провели работу по адаптации учебных программ к единой школе, так как с переходом на «Временные программы...» выяснилось, что предложенный в них способ изложения учебного материала оказался довольно сложным для применения в учебной практике. В школах единого типа не было единых требований к преподаванию дисциплин, отсутствовала преемственность в содержании учебного материала между школами I и II ступеней [Там же. C. 18]. Всё это противоречило сути единой школы. Составление согласованных между собой программ для школ I и II ступеней было закончено в 1921 г., после этого началась работа по составлению и согласованию с ними программ для школ III ступени.

Урегулирование финансовой деятельности дороги позволило полностью оплачивать по смете Земельного и Учебного отделов КВЖД содержание 66 железнодорожных и поселковых школ [ Там же. С. 30], или почти 93\% ведомственной сети. Бюджет частных школ, подведомственных дороге, составляла плата за обучение и субсидии, которые могли поступать от поселковых управлений, культурно-просветительских организаций или правления КВЖД. Субсидию от КВЖД получали также три вуза, не входивших в ведомственную сеть: Русско-китайский политехникум, Юридический факультет и Высшая медицинская школа. Рассматривался вопрос о передаче Учебному отделу частных гимназий Я.А. Дризуля и М.А. Оксаковской, и хотя передача не состоялась, эта попытка отражает стремление русской 
администрации дороги расширить ведомственную учебную сеть и номенклатуру специальностей. Таким образом, ещё до установления на КВЖД совместного управления русская администрация стала переходить к единому типу образовательного учреждения и сумела сформировать независимую от китайской администрации ОРВП сеть ведомственных школ.
Переход дороги в совместное советско-китайское управление усилил политические позиции Китая. В декабре 1924 г. Главноначальствующий ОРВП генерал Чжу Циньлан ввёл в бывшей полосе отчуждения новую систему руководства учебными заведениями, расширившую контроль китайской администрации за школами на КВЖД [11. С. 202]:

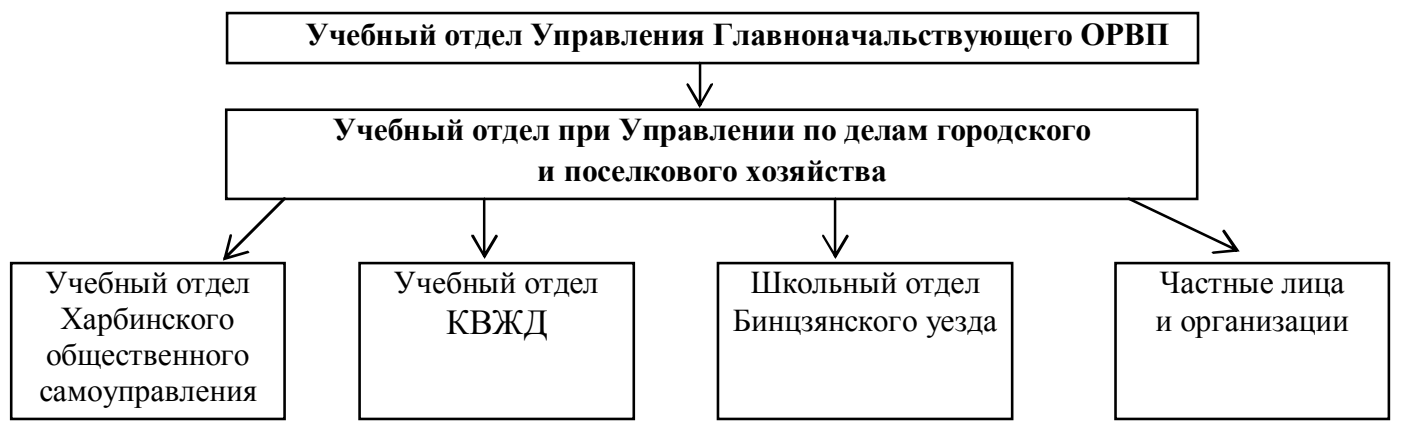

Русские школы получили статус учебных заведений иностранных резидентов. Для внесения изменений в учебные программы или систему управления, приём экстернов, открытия или закрытия школ требовалось согласование Учебного отдела при Управлении по делам городского и поселкового хозяйства.

При этом советская администрация дороги и Учебный отдел КВЖД сохранили за собой право оперативного управления сетью подведомственных им школ и свободу действий по реализации политики советского государства в сфере образования на КВЖД.

Советскому управляющему КВЖД подчинялись комитет образовательных учреждений (КОУ) и комитет по делам высших и специального типа учебных заведений, которые наблюдали за общим состоянием дел в учебных заведениях, пользующихся субсидиями или получавших поддержку от дороги в виде бесплатного помещения, отопления, освещения и т.п. Все постановления данных комитетов вступали в силу после их утверждения советским управляющим КВЖД. Последний утверждал председателя первого комитета и назначал председателя второго на неопределенный срок; и только по его распоряжению они освобождались от занимаемой должности. Вопросы по учебновоспитательной и организационной работе, открытию специальных учебных заведений решались на совместных заседаниях обоих комитетов под председательством управляющего дорогой или его заместителя.

Учебный отдел КВЖД являлся исполнительным и распорядительным органом КОУ; на него возлагалось непосредственное заведование образовательными учреждениями, содержащимися на средства КВЖД, и наблюдение за общим состоянием дела в учебных заведениях, пользующихся её субсидиями.

Районы участков Службы Пути на КВЖД курировали районные школьные комитеты (РШК), число которых соответствовало числу участков на КВЖД. В полномочия РШК входил контроль за исполнением решений КОУ учебными заведениями, заботы о хозяйственных нуждах школ, составление смет по своим участкам на предстоящий учебный год, разреше- ние конфликтных ситуаций, возникавших между школьными администрациями и родительскими комитетами, а также материальная поддержка бедных учеников (обеспечение горячими завтраками, одеждой и обувью, учебниками и др.).

Приход советской администрации сопровождался сменой руководящего состава на линии дороги. Вместо Н.В. Борзова, возглавлявшего учебный отдел КВЖД с 1906 г., назначили креативно настроенного по отношению к советской власти сменовеховца Н.В. Устрялова. Законодательной основой советской школьной реформы на КВЖД стал декрет ВЦИК от 16 октября 1918 г., утвердивший «Положение о единой трудовой школе РСФСР» и «Основные принципы единой трудовой школы РСФСР». Реформирование ведомственных учебных заведений на КВЖД коррелировались с реформой Единой трудовой школы в СССР, считавшейся одним из приоритетных направлений советского модернизационного проекта.

В соответствии с идеологической установкой ВКП(б) Китай и китайский пролетариат рассматривались как потенциальные партнёры СССР в борьбе за мировую революцию. Поэтому при формировании политики относительно подведомственной ей части образовательного потенциала советская администрация КВЖД руководствовалась принципом национального равноправия. Граждане СССР и Китая могли обучать и воспитывать детей в соответствии с требованиями законодательства своих стран, русские и китайские дети имели равные права на получение образования, китайские власти были полномочны осуществлять общий надзор за деятельностью всех учебных заведений на КВЖД [10. С. 38]. Последнее интерпретировалось как признание суверенного права китайского народа.

Реформа сопровождалась расширением сети ведомственных школ и модернизацией их материальнотехнической базы. При первом советском управляющем КВЖД А.Н. Иванове для этой цели Учебному отделу выделили на 1925 и 1926 гг. «невиданный ещё на дороге» кредит на сумму 25000 и 23807 руб. соответственно. Школы II ступени получили целевое фи- 
нансирование для переоборудования химических и физических лабораторий в размере 900 руб. на школу; на переоборудование естественноисторических кабинетов 34 школам I ступени выделили по 200 руб., а школам II ступени - по 300 руб. [10. С. 28]. Часть средств направили на модернизацию школьных мастерских, развитие пришкольных участков и другие пособия школам.

В соответствии с принципом трудового обучения для развития в детях навыков к труду и поощрения их самодеятельности по самообслуживанию семьи и школы в железнодорожных учебных заведениях были открыты или восстановлены существовавшие ранее вспомогательные учреждения: мастерские для обучения столярному, слесарному и картонажнопереплетному ремеслу, выпиливанию и выжиганию по дереву. Получили развитие пришкольные садовоогородные участки и приусадебные хозяйства, где школьники овладевали агротехническими и специальными ботаническими знаниями и научными методами ведения сельского хозяйства.

На 1 января 1926 г. ведомственная сеть включала 102 учебных заведения общего и профессионального образования с 13814 учащимися [12. С. 312-314]. В том числе: 76 русских школ I, II и III ступени (52, 19 и 5), 17 китайских школ, 7 профессиональных школ и 2 вуза. Для удовлетворения потребности в образовании детей из семей русских и китайских железнодорожных служащих, проживавших на отдаленных разъездах, на линии дороги открыли 8 общежитий на 344 пансионера [10. С. 27]. Однако из-за отсутствия данных по численности русских и китайских пансионеров определить их соотношение по национальному признаку не представляется возможным.

По сравнению с 1925 г. смета школьного строительства в 1926 г. увеличилась на 60\% [Там же. С. 36]. Из 93 ведомственных начальных и средних школ администрация КВЖД полностью оплачивала содержание 66 учебных заведений (54\%), из них китайских - 25 и русских - 41. При этом 46\% русских школ самостоятельно формировали свои бюджеты, основу которых составляла плата учащихся за обучение и дотация от Учебного отдела КВЖД на коммунальные платежи.

Таким образом, в начале модернизации системы образования на КВЖД наблюдались быстрый темп наращивания сети ведомственных учебных заведений, их финансовая стабилизация и укрепление материальной базы. В сравнении с 1923 г. общая численность ведомственных учебных заведений увеличилась на $44 \%$, численность учащихся - на $38 \%$. Динамика общего образования отражала тенденцию сокращения разрыва между численностью начальных и средних школ.

Целью первой реформы школы в Советской России провозглашалось воспитание человека новой эпохи, что, в частности, определило тесную связь советской системы образования с идейно-политическим компонентом. Новые идеи транслировались в советскую школу через содержание учебных программ и учебной литературы. Школьные библиотеки КВЖД пополняли советскими учебниками в централизованном порядке. Так, в 1926 г. из Москвы прислали 4 справочных библиотеки для учителей и 45 комплек- тов учебников [10. С. 27]. Следовательно, учебной литературой из СССР сумели обеспечить 48\% ведомственных школ. Факт поставки советских учебников в Маньчжурию важен также для понимания того, по каким программам учились в школах КВЖД. Проведённый в своё время автором данной статьи сравнительный анализ «Временных программ обучения в начальных школах» 1916 г. и комплексных программ Наркомпроса 1923 г. показал, что моделью для советских комплексных программ послужили учебные программы Игнатьева [13. С. 20-21]. Составители советских программ также отказались от предметного принципа подачи материала и сгруппировали его в предметные комплексы: 1) природа и человек; 2) общество; 3) труд. От программ Игнатьева (и созданных на их основе учебных программ для школ КВЖД) советские учебные программы отличались включением в естественнонаучный цикл обществоведческого и политико-экономического компонента, дающего представление о государственном строе Советской России, марксистской политической экономии и современности, марксистском учении о государстве диктатуры пролетариата и основах экономической политики большевиков. В программах предшественников такая связь была исключена.

В октябре 1924 г. советская администрация упразднила Церковный отдел КВЖД, а с 1 января 1925 г. отменила кредиты на преподавание Закона Божия в ведомственных школах, закрыла церкви при учебных заведениях, отменила утреннюю молитву и вообще какое-либо присутствие РПЦ в школе [14. С. 161-162]. Атеизм и марксистские идеи в содержании учебных программ становились ключевыми моментами в формировании новой (советской) идентичности.

По данным Статистического бюро КВЖД, в 19251926 гг. по учебным программам школ СССР занимались в пяти частных русских школах III ступени (9-летках), подведомственных КВЖД и расположенных на станциях Бухэду, Цицикар, Имяньпо, Ханьдаохэцзы и Пограничная [12. С. 313]. В Харбине были две средние школы, хотя и неподведомственные Учебному отделу, но работавшие по программам школ II ступени СССР: 7-классная Смешанная русско-китайская реальная гимназия Г.А. Лас и 8-классная Первая харбинская общественная гимназия, включенная в сеть школ СССР [11. С. 203-204].

Организация занятий в ведомственных школах по инновационным американским методикам - Дальтонплану Е. Паркхерст и методу проектов Дж. Дьюи ориентировала учеников на исследовательские задачи и самостоятельную работу и предлагалась в качестве альтернативы дореволюционной классно-поурочной системе. Первым учебным заведением на КВЖД, организовавшим учебный процесс по Дальтон-плану, была школа II ступени им. инженера Юговича в Харбине (бывшая 3-я гимназия) [15. С. 40].

Поощрялось всемерное развитие ученической самодеятельности путем создания различных общественных организаций. Введённое в 1917 г. в ведомственных школах самоуправление просуществовало недолго и с 1919 г. было свёрнуто, и Советы школ заменили традиционными педсоветами. В советский 
период стали вводить формы самоуправления, аналогичные принятым в учебных заведениях СССР: советы народного образования (CHO) и ученические комитеты (учкомы), которые получили равные права с администрацией и педагогическим советом школы. Поощрялось всемерное развитие ученической самодеятельности путем создания различных общественных организаций. Самыми распространенными были санитарные комиссии и разного рода кружки. В середине 1920-х гг. они работали во всех школах на линии дороги. Члены санкомиссий следили за чистотой и порядком в школьных помещениях, разъясняли сверстникам и демонстрировали на личном примере элементарные правила личной гигиены, занимались санитарным просвещением дома. Подавляющее большинство кружков создавалось поклассно. При этом научно-образовательные кружки преобладали над литературными, драматическими, художественными и спортивными, что давало повод говорить о доминировании руководителей-взрослых в кружковом движении и подчинении его учебным целям, а следовательно, об ограничении самодеятельности учеников [10. С. 29].

Постоянно или эпизодически учащиеся выпускали оперативные издания - стенгазеты, школьные газеmы и икольные журналь. Тематические материалы таких изданий отражали новую политическую и социальную реальность: «Красный Октябрь», «Труд и Школа», «К Труду и Знанию», «Наш санитар», «Наш живой уголок», «Ленинские Дни в Школе», «Два года без Ленина», «Как жил и работал Ленин», «Ленин и Октябрь», «Ленин ранен», «Что рассказали школьники о Ленине» и т.п. Наиболее удачными школьными журналами считались «Наше Эхо» и «Первопуток».

Школьные кооперативы базировались на самодеятельности детей и товарном или денежном кредите от действовавших кооперативных организаций. Минимальный вступительный взнос для школьников составлял 5 копеек, а паевой - 50 копеек в год, предусматривалась выплата взносов в рассрочку [Там же. С. 30]. Через школьные кооперативы учащиеся обеспечивали себя письменными принадлежностями и материалами для ручного труда, реже - учебниками. По данным Учебного отдела КВЖД, развитие кооперативного движения тормозилось из-за нехватки финансовых средств, двухсменных занятий в школах и отсутствия соответствующего организационного опыта у детей. Тем не менее в 1926 г. кооперативным движением было охвачено уже 25-30\% от общего числа учащихся в образовательных заведениях КВЖД, что является, на наш взгляд, довольно приличным показателем для столь короткого срока существования школьной кооперации. По всей видимости, школьная кооперация на КВЖД была специфическим явлением, так как в Дальневосточной области РСФСР она либо отсутствовала, либо находилась в зачаточном состоянии, во всяком случае в официальных источниках о ней не упоминали.

Советская школа вовлекалась в политическую жизнь. Комсомольские и пионерские организации появились на КВЖД в самом начале 1920-х гг. Первый съезд российского комсомола Северной Мань- чжурии состоялся в марте 1921 г., а первая пионерская организация появилась в 1923 г. [3. С. 86]. В советский период пионерскому движению старались придать массовый характер. Так, конференция учащихся советских школ Харбина (1925) призвала «вести неустанную пропаганду рабочего дела и воспитывать себя в духе учения великого пролетарского вождя - Ленина» [Там же]. Основной костяк пионерского движения составляли дети служащих КВЖД, членов ВКП(б) или советских профсоюзов. В 1926 г. пионерская организация на КВЖД насчитывала 3 тыс. участников [14. С. 176], её удельный вес в общей численности учащихся железнодорожных школ составлял около 22\%. Следовательно, в пионерском движении участвовал каждый пятый ученик, и считать его в полном смысле массовым нельзя, но идейный потенциал пионерского движения делал его одним из ключевых факторов формирования советской идентичности.

Задачу модернизации материально-технической базы ведомственного образования в полном объёме решить не удалось. Собственными, специально построенными для школьных нужд помещениями располагали $11 \%$ русских школ для граждан СССР. Остальные учебные заведения ещё с дореволюционного времени довольствовались приспособленными под учебный процесс воинскими казармами или арендовали помещения у частных лиц. В условиях дефицита школьных помещений и постоянного притока учащихся ввели занятия в две или три смены.

Что же касается учебных заведений для китайцев, то ещё в дореволюционный период для них в Квантунской области, в посёлках на линии КВЖД и в Харбине были открыты несколько русско-китайских общеобразовательных и профессиональных школ, в которых занимались по программам русских учебных заведений [5. С. 224-227, 237-238]. С переходом полосы отчуждения под китайскую юрисдикцию на КВЖД стали открывать китайские школы, работавшие по планам Министерства народного образования Китая. Обучение в начальной китайской школе составляло 6 лет и включало I и II ступени с четырёх- и двухгодичными учебными курсами; средние учебные заведения делились на I и II ступени со сроками обучения по 3 года на каждой. В период Республики в новой китайской школе произошел разрыв с традиционной конфуцианской системой воспитания и образования, ориентированной на этико-политические вопросы и изучение древних китайских классиков. Новая китайская школа опиралась на естественнонаучный цикл, который являлся двигателем европейской науки, ручной труд, изучение ремесел технической специальности или другие профуклоны [16. С. 87]. Разделение школы на две ступени, введение таких дисциплин, как физика, химия, естествознание и лабораторное их усвоение, принцип трудового обучения делали новую китайскую образовательную модель отчасти схожей с русской (советской) моделью общеобразовательной школы. Сходство дополнялось организацией занятий в китайских школах по методу Дж. Дьюи, положенным в основу новой системы воспитания и образования [17. С. 62]. Наиболее продвинутой китайской средней школой ведомства КВЖД 
считалось училище Пуюй. В условиях слаборазвитой системы технических школ на линии дороги усиление элементов промышленно-технического и профессионального образования в составе курса данной школы приобретало особую актуальность для подготовки национальных кадров и распространения технических знаний среди китайского населения.

С 1926 г. началось обострение отношений между СССР и Китаем из-за попыток маршала Чжан Цзолина вытеснить СССР и захватить КВЖД. В контекст этой борьбы входило переподчинение китайским властям подведомственных железной дороге учебных заведений. Националистически настроенная китайская администрация рассматривала новую русскую школу как опасный источник пропаганды коммунистических идей, влиявший на умонастроения китайского населения ОРВП и разлагающий русскую и китайскую молодёжь.

Слухи о предстоящей «китаизации» железнодорожных школ и упразднении Учебного отдела КВЖД вызывали тревогу у служивших на дороге советских подданных. Вопрос о правомерности таких действий со стороны китайских властей задавали председателю правления КВЖД Лю Шанцину на Мукдэнской конференции (май 1926 г.). Лю Шанцин успокаивал советскую сторону заявлением о том, что слухи об изменении деятельности учебного отдела действительно существуют, но значения не имеют [18. С. 1]. Однако спустя три месяца (24 августа 1926 г.) глава ОРВП генерал Чжан Хуансян издал указ об упразднении Учебного отдела КВЖД и передал его дела и сметные суммы в распоряжение образованного им Управления народного просвещения ОРВП, а 4 сентября китайцы захватили и опечатали помещение Учебного отдела [Там же. С. 2].

Что же касается ответной реакции советского правительства на эти события, то принятые в мартесентябре 1926 г. решения Политбюро ЦК ВКП(б) защищали, в первую очередь, экономические интересы советского государства, но мало способствовали защите интересов советских граждан в сфере образования. Решением 18 марта руководство КВЖД передали Наркомату путей сообщения, 13 мая приняли решение об изъятии части принадлежавшей советской стороне прибыли «на общегосударственные нужды СССР», а после захвата Учебного отдела КВЖД китайцами на заседании Политбюро ЦК ВКП(б) 7 сентября 1926 г. решили «воздержаться от открытия новых школ» [14. С. 114].

С декабря 1927 г. управление русскими железнодорожными школами перешло в 4-й отдел Департамента народного просвещения (ДНП). Руководителем этого отдела назначался советский чиновник, который подчинялся теперь вышестоящему китайскому администратору. Все высшие учебные заведения, включая Русско-китайский политехнический институт и Юридический факультет, переподчинили в непосредственное ведение Управления Главноначальствующего ОРВП [19. С. 231]. Перераспределение властных полномочий содействовало усилению давления китайской администрации на железнодорожные школы для русских детей. С приходом в ноябре 1928 г. на должность начальника ДНП Чжан Гочена, в прошлом личного секретаря маршала Чжан Сюэляна, контроль над русскими школами стал принимать тотальный характер. Школьные мероприятия (концерты, спектакли, школьные вечера и собрания, заседания родительского комитета и т.п.) подвергались предварительной цензуре в ДНП за 10 дней до начала проведения мероприятия. Переписка осуществлялась только на китайском языке через ДНП, минуя 4-й отдел. Приказами китайского начальника ДНП № 249 и № 421 от 5 февраля и 4 марта 1929 г. вводились правила, регламентирующие организационную жизнь школ, включая порядок и сроки проведения мероприятий. Под контроль китайской администрации была поставлена учебная работа в школах КВЖД и проведена смена государственной символики [14. С. 125-126].

Появились диспропорции в распределении финансовых средств для русских и китайских школ. Так, фонд оплаты труда по русским школам в 1926 г. вырос на $20,4 \%$, а по китайским - на 70,4\%. Стоимость содержания одного ученика в русских школах I ступени составила 69 руб. 87 коп., в китайских - 77 руб. 53 коп., в русских школах II ступени - 137 руб. 70 коп., в китайских - 272 руб. 25 коп. [10. С. 29, 36]. Официальное объяснение разницы в стоимостном содержании учащихся сводилось к тому, что школьное строительство для детей китайских рабочих и служащих началось в более благоприятных политических условиях, а также к более дорогой стоимости китайских учебных пособий и материалов. Последний момент официальной версии воспринят и некоторыми современными исследователями [4. С. 23].

В 1928 г. советская администрация признала тот факт, что для русских детей в 1927/28 учебном году КВЖД не открыла ни одной новой школы, прекратилось выделение средств на ремонт и капитальное строительство, но при этом число учащихся в школах для граждан СССР увеличилось за год на 1100 чел. [15. C. 38,46$]$.

В целом материально-техническое состояние советских школ ухудшилось. По официальным данным, 70\% русских школ оставались в приспособленных помещениях, по размерам, кубатуре и расположению не соответствовавших санитарно-гигиеническим требованиям. По примеру Советской России в железнодорожных школах стали вводить «голодную» норму объёма школьных помещений, снижавшую санитарно-гигиенические нормативы на одного ученика. В СССР она составляла 5 кв. аршин (3,6 кв. м), на КВЖД - 5,38 кв. аршин (3,8 кв. м) [Там же. С. 28]. Русские ученики продолжали заниматься в переполненных классах в две-три смены; стала ощущаться нехватка мастерских ручного труда, спортивных залов, кабинетов физики и химии.

Началось снижение социальной мобильности советского образования на КВЖД. Вследствие дефицита школьных помещений в 1927/28 учебном году появились случаи отказов в приёме в русские (советские) учебные заведения. Так, 2-я гимназия в Харбине (школа II ступени), обслуживавшая харбинский железнодорожный узел с участками по трём направлениям до станции Ашихэ, Аньда и Лаошаогоу, имела 
16 классов с 640 учащимися, из которых 300 чел. были приезжими. Занятия проводились в две смены в двух зданиях, расположенных в разных местах, санитарно-гигие-нический норматив на 1 ученика школа уменьшила до 2,5 кв. м. В 1927/28 учебном году отказали в приёме 70 детям. Тогда же по аналогичной причине отказали в приёме 50 русским детям в 5-й школе II ступени (7-летке) на станции Мулин. В 11-й гимназии на станции Имяньпо, в которой учились 650 человек и работало общежитие, обеспеченность школьными помещениями была в 2,5 раза ниже нормы, из-за чего 5 младших групп занимались в общежитии, а в приёме отказали 70 ученикам. Подобные случаи имелись и в других ведомственных школах. По неполным данным, в 1927/28 учебном году почти две сотни русских детей - подданных СССР не получили доступа в ведомственные школы [15. С. 40 42]. В складывавшейся ситуации введение всеобщего начального обучения для детей служивших на КВЖД советских граждан оказалось под вопросом. Для детей китайских служащих КВЖД введение начального всеобуча завершилось в 1926 г. Не отказывали в приеме в китайские школы и детям частных для дороги лиц там, где не было поселковых школ. Таких учеников было 24,3\% от общего числа учащихся в китайских школах, в русских школах - 12,7\%, при этом наполняемость классов в русских школах составляла 35-40 чел., а в китайских - 20-25 [10. С. 33].

Динамика подведомственных железной дороге школ после установления фактического контроля над ними китайской администрацией ОРВП приведена в следующей таблице, составленной на основании данных ведомственной статистики.

Ведомственные учебные заведения во второй половине 1920-х гг. (Харбин - станции КВЖД)

\begin{tabular}{|l|c|c|c|}
\hline \multicolumn{1}{|c|}{ Учебные заведения } & \multicolumn{3}{|c|}{ Год } \\
\cline { 2 - 4 } & 1926 & 1927 & 1928 \\
\hline По г. Харбину & 29 & 26 & 16 \\
\hline По станциям на линии КВЖД & 73 & $\begin{array}{c}\text { Нет } \\
\text { свед. }\end{array}$ & 19 \\
\hline Всего & 102 & $\begin{array}{c}\text { Нет } \\
\text { свед. }\end{array}$ & 35 \\
\hline
\end{tabular}

Источник: [12. С. $312-314 ; 15$. С. 46; 19. С. 239-241; 20. С. $111-$ 115].

В 1928 г. в распоряжении советской администрации осталось 35 ведомственных школ, или 1/3 часть от некогда принадлежавшей ей сети учебных заведений. В то же время растущий грузооборот на КВЖД требовал постоянного обновления и притока рабочей силы. Имеющиеся в распоряжении советской администрации ведомственные школы уже не восполняли потребности в воспроизводстве собственных квалифицированных кадров специалистов [15. С. 38], что было чревато снижением производительности труда, а следовательно, и снижением доходов, получаемых от эксплуатации дороги. Последнее обстоятельство тревожило советское руководство, так как часть полученной от эксплуатации КВЖД прибыли, принадлежавшая советской стороне, направлялась для решения задачи ускорения темпов индустриального строительства в СССР. В связи с этим советская администрация КВЖД объявила о начале реализации 5-летнего плана школьного строительства для детей железнодорожников - граждан СССР на период 1928-1932 гг. [15]. Упорядочение работы ведомственных школ вписывалось в контекст воспроизводства квалифицированной рабочей силы на КВЖД и реализации плановых заданий первой пятилетки в СССР. Однако из-за последующих военно-политических событий (вооружённого конфликта на КВЖД между СССР и Китаем 1929 г. и японской оккупации Маньчжурии, осуществлённой в сентябре 1931 г.) поставленная задача решена не была.

Таким образом, комплекс мер по реформированию сети ведомственных школ, на практике воплощавший политику Советского государства в сфере образования, был реализован на линии КВЖД в довольно сжатые сроки, в 1924-1926 гг. В этот период законодательно введён единый тип образовательного учреждения - «единая трудовая школа»; учебно-воспитательный процесс трансформировался на новых принципах воспитания и формах повседневной практики, принятых в советских школах и адаптирующих учеников к новой социально-политической реальности. Реформирование школ на КВЖД коррелировалось с реформой единой трудовой школы, интегрировало их в советское образовательное пространство.

Число ведомственных школ достигло своего максимума, существенно увеличился и контингент учащихся. В целом образовательная политика советской администрации обеспечила поступательную динамику школьного строительства и стабилизацию финансового положения ведомственных учебных заведений, хотя задача модернизации материально-технической базы железнодорожных школ из-за обострения военно-политической обстановки на КВЖД была решена не полностью.

Следует подчеркнуть, что советская реформа единой трудовой школы непосредственно связана с реформой единой школы П.Н. Игнатьева, начатой в 1915-1916 гг. и продолженной на КВЖД в 19171923 гг. В данном контексте советские комплексные программы можно рассматривать как модифицированные на основе положений «Декларации о единой трудовой школе» «Временные программы...» П.Н. Игнатьева. Отличительной чертой советской реформы являлась тесная связь учебно-воспитатель-ного процесса с идеологией и политикой. При этом его содержание трансформировалось по аналогии со школами в СССР и имело целеполаганием формирование новой (советской) идентичности.

Советская школьная реформа проходила на территории другого государства и прямо зависела от военно-политической обстановки, складывавшейся на линии КВЖД. Соперничество между СССР и Китаем за обладание железной дорогой закончилось вытеснением советской стороны, а в сфере образования привело к свёртыванию школьной реформы. На фоне угрозы потери КВЖД она утрачивала в глазах советского правительства свою актуальность.

В 1927-1929 гг. система ведомственных учебных заведений функционировала в условиях нарастающего идеологического и административного давления с китайской стороны и существенного сокращения в школьном строительстве на КВЖД объёмов влияния 
советской администрации. Прямым следствием политических манифестаций китайского правительства явилось перераспределение в свою пользу материаль- ных ресурсов школьного строительства, сопровождавшееся нарушением прав русских детей - подданных СССР на получение образования.

\section{ЛИТЕРАТУРА}

1. Еропкина О.И. Русская школа в Маньчжурии первой трети XX века: тенденции развития и проблемы : автореф. дис. ... канд. пед. наук. M., 2002. 170 c. URL: http://www.lib.ua-ru.net/diss/cont/108124.html (дата обращения: 20.08.2016).

2. Косинова О.А. Традиции российского педагогического зарубежья на территории Китая в конце XIX - первой половине XX веков : автореф. дис. .... д-ра пед. наук. М., 2009. 43 с.

3. Потапова И.В. Русская система образования в Маньчжурии. 1898-1945 годы : дис. ... канд. ист. наук. Хабаровск, 2006.251 с.

4. Чэ Чуньинь. Научно-образовательная и духовно-культурная деятельность российской диаспоры в Китае (1920-1940-е годы) : дис. ... канд. ист. наук. Владивосток, 2014. 187 с.

5. Этнокультурные и социально-экономические проблемы освоения смежных территорий Северо-Восточной Азии: российский Дальний Восток, Северо-Восточный Китай, о Хоккайдо (Япония) (XVII - первая половина ХХ в.). Владивосток : Рея, 2013. 256 с.

6. Материалы по реформе средней школы: примерные программы и объяснительные записки, изданные по распоряжению г. Министра народного просвещения. Петроград : Сенатская тип., 1915. 553 с.

7. Государственный архив Иркутской области. Ф. 63. Оп. 1. Д. 739

8. Краткий обзор деятельности Учебного отдела дороги // Экономический вестник Маньчжурии. Харбин. 1923. № 23-24. С. 16-20.

9. Государственный архив Хабаровского края. Научно-справочная библиотека. Ед. хр. 2303.

10. Филиппович К. Советские и китайские школы на КВЖД // Вестник Маньчжурии. Харбин. 1926. № 5. С. $27-39$.

11. Харбин-Фуцзядянь: торгово-промышленный железнодорожный справочник / под ред. К. Очеретина. Харбин : Изд. Харбин. коммерч. агентства «Транспечати» НКПС, 1925.

12. Статистический ежегодник Экономического Бюро КВЖД. 1926. Харбин : Тип. КВЖД, 1926.

13. Белоглазова С.Б. Тихоокеанская Россия в контексте социокультурных трансформаций в 20-е годы XX в. // Материалы ХХХІ Российскояпонского симпозиума историков и экономистов и района Кансай (Япония). 9-10 сентября 2015 г. : сб. ст. Владивосток : Дальнаука, 2016. C. 20-24.

14. Кротова М.В. СССР и российская эмиграция в Маньчжурии (1920-1950-е гг.) : дис. ... д-ра ист. наук. СПб., 2014.536 с.

15. Пятилетний план строительства школ для детей железнодорожников - граждан СССР // Вестник Маньчжурии. Харбин. 1928. № 6. С. $38-49$.

16. Ершов М.Н. Индустриализация Китая и запросы технического образования // Вестник Маньчжурии. Харбин. 1928. № 7. С. 76-87.

17. Филиппович К.А. Система народного образования в Китае // Вестник Маньчжурии. Харбин. 1927. № 5. С. 61-71.

18. К положению на КВЖД // Вестник Маньчжурии. Харбин. 1926. № 7. С. 1-3.

19. Весь Харбин на 1927 год / ред.-изд. С.Т. Терновский. Харбин, 1927. 417 с.

20. Весь Харбин: адресная и справочная книга на 1926 год / ред.-изд. С.Т. Терновский. Харбин, 1926.534 с.

Статья представлена научной редакцией «История» 25 августа 2017 г.

\section{THE REFORM OF DEPARTMENTAL SCHOOLS AT THE CHINESE EASTERN RAILWAY IN THE SECOND HALF OF THE 1920S}

Vestnik Tomskogo gosudarstvennogo universiteta - Tomsk State University Journal, 2017, 424, 58-66.

DOI: $10.17223 / 15617793 / 424 / 8$

Svetlana B. Beloglazova, Institute of History, Archaeology and Ethnography of the Peoples of the Far East, FEB RAS (Vladivostok, Russian Federation). E-mail: Beloglazov1@yandex.ru

Keywords: China; USSR; CER; reform; school.

The history of Russian education in Manchuria is an integral part of the history of the national education system of Russia. This article is devoted to the aspect of the history of Russian schools in the near abroad poorly studied in Russian historiography - the Soviet school reform at the Chinese Eastern Raailway (CER). The writing of the article is determined by two factors: creative transformation in the evaluation of the historical phenomenon of the Soviet school and the activation of Russian-Chinese integration processes at the present stage of reforms in Russia. The study of the historical experience of the Soviet education reform at the CER fits into this context, and a retrospective reflection on the outcomes of the modern education reform and discussions about the future of Russian-Chinese cooperation actualizes the appeal to the chosen research topic. New materials from departmental editions of the Chinese Eastern Railway were first introduced into the academic use in this article. The research tradition that developed in the Soviet period linked the reform of the Russian school of the 1920s exclusively with the transformation of the Soviet power and contrasted them with the pre-October period. The author made an attempt to revise the tradition of the methodological gap in the study of the history of education of the Imperial and Soviet periods. For the first time in the national historiography the relations between the reforms of the united school of Count P.N. Ignatiev launched in 1915-1916 and continued at the CER in 1917-1923 and the Soviet reform of the united working school completed at the CER in the second half of the 1920s are shown. A distinctive feature of the Soviet school reform from transformations of the previous period was the close connection of the educational process with ideology and politics. At the same time, the school reform at the CER was correlated with the reform of the united working school with the aim of integrating departmental schools in the educational space of the USSR and aimed at forming a new (Soviet) identity. The complex of measures for reforming the network of departmental schools was implemented at the CER in the shortest time possible and ended with the introduction of a single type of educational institution, a maximum growth in the number of departmental schools and students. The educational process was transformed on the new principles of training and forms of everyday practice adopted in Soviet schools that adapted students to the new socio-political reality. Due to the rivalry between the USSR and China for the possession of the CER, the system of departmental schools functioned in the conditions of increasing administrative pressure from the Chinese side and the decline in the influence of the Soviet administration, which led to the curtailment of the reform in the late 1920s. A direct consequence of the political manifestations of the Chinese government was the redistribution of material resources of school building at the CER, accompanied by the violation of rights of Russian children - citizens of the USSR - to receive education. 


\section{REFERENCES}

1. Eropkina, O.I. (2002) Russkaya shkola v Man'chzhurii pervoy treti XX veka: tendentsii razvitiya i problemy [Russian school in Manchuria in the first third of the 20th century: development trends and problems]. Abstract of Pedagogy Cand. Diss. Moscow. [Online] Available from: http://www.lib.ua-ru.net/diss/cont/108124.html. (Accessed: 20.08.2016).

2. Kosinova, O.A. (2009) Traditsii rossiyskogo pedagogicheskogo zarubezh'ya na territorii Kitaya v kontse XIX - pervoy polovine XX vekov [Traditions of Russian pedagogical abroad in China at the end of the 19th - first half of the 20th centuries]. Abstract of Pedagogy Dr. Diss. Moscow.

3. Potapova, I.V. (2006) Russkaya sistema obrazovaniya v Man'chzhurii. 1898-1945 gody [Russian education system in Manchuria. 1898-1945]. History Cand. Diss. Khabarovsk.

4. Che Chunyin. (2014) Nauchno-obrazovatel'naya i dukhovno-kul'turnaya deyatel'nost' rossiyskoy diaspory v Kitae (1920-1940-e gody) [Scientificeducational and spiritual-cultural activities of the Russian diaspora in China (1920s-1940s)]. History Cand. Diss. Vladivostok.

5. Larin, V.L. et al. (2013) Etnokul'turnye i sotsial'no-ekonomicheskie problemy osvoeniya smezhnykh territoriy Severo-Vostochnoy Azii: rossiyskiy Dal'niy Vostok, Severo-Vostochnyy Kitay, o Khokkaydo (Yaponiya) (XVII - pervaya polovina XX v.) [Ethno-cultural and socio-economic problems of the development of the adjacent territories of Northeast Asia: the Russian Far East, Northeast China, Hokkaido (Japan) (17th - first half of 20th centuries)]. Vladivostok: Reya.

6. Senate Typography. (1915) Materialy po reforme sredney shkoly: primernye programmy i ob"yasnitel'nye zapiski, izdannye po rasporyazheniyu g. Ministra narodnogo prosveshcheniya [Materials on secondary school reform: exemplary programs and explanatory notes issued by the order of the Minister of Education]. Petrograd: Senatskaya tip.

7. State Archive of Irkutsk Oblast. File 63. List 1. File 739. (In Russian).

8. Ekonomicheskiy vestnik Man'chzhurii. (1923) Kratkiy obzor deyatel'nosti Uchebnogo otdela dorogi [A brief overview of the activities of the Training Department of the Railway]. Ekonomicheskiy vestnik Man'chzhurii. 23-24. pp. 16-20.

9. State Archive of Khabarovsk Krai. Reasearch and Reference Library. Unit 2303. (In Russian).

10. Filippovich, K. (1926) Sovetskie i kitayskie shkoly na KVZhD [Soviet and Chinese schools on the ECR]. Vestnik Man'chzhurii. 5. pp. 27-39.

11. Ocheretin, K. (ed.) (1925) Kharbin-Futszyadyan': torgovo-promyshlennyy zheleznodorozhnyy spravochnik [Harbin-Fujianian: trade and industrial railway directory]. Kharbin: Izd. Kharbin. Kommerch. Agentstva "Transpechati" NKPS.

12. ECR Typography. (1926) Statisticheskiy ezhegodnik Ekonomicheskogo Byuro KVZhD. 1926 [Statistical Yearbook of the Economic Bureau of the ECR. 1926]. Kharbin: Tip. KVZhD.

13. Beloglazova, S.B. (2016) [Pacific Russia in the context of socio-cultural transformations in the 1920s]. Proceedings of the XXXI RussianJapanese symposium of historians and economists and the Kansai region (Japan). September 9-10, 2015. Vladivostok: Dal'nauka. pp. 20-24.

14. Krotova, M.V. (2014) SSSR i rossiyskaya emigratsiya v Man'chzhurii (1920-1950-e gg.) [The USSR and the Russian emigration in Manchuria (1920s-1950s)]. History Dr. Diss. St. Petersburg.

15. Vestnik Man'chzhurii. (1928) Pyatiletniy plan stroitel'stva shkol dlya detey zheleznodorozhnikov - grazhdan SSSR [Five-year plan for the construction of schools for children of railwaymen - citizens of the USSR]. Vestnik Man' chzhurii. 6. pp. 38-49.

16. Ershov, M.N. (1928) Industrializatsiya Kitaya i zaprosy tekhnicheskogo obrazovaniya [Industrialization of China and requests for technical education]. Vestnik Man'chzhurii. 7. pp. 76-87.

17. Filippovich, K.A. (1927) Sistema narodnogo obrazovaniya v Kitae [System of public education in China]. Vestnik Man'chzhurii. 5. pp. 61-71.

18. Vestnik Man'chzhurii. (1926) K polozheniyu na KVZhD [On the situation at the ECR]. Vestnik Man'chzhurii. 7. pp. 1-3.

19. Ternovskiy, S.T. (ed.) (1927) Ves' Kharbin na 1927 god [All Harbin in 1927]. Kharbin: tip. Kitayskoy vostochnoy zh. d.

20. Ternovskiy, S.T. (ed.) (1926) Ves' Kharbin: adresnaya i spravochnaya kniga na 1926 god [All Harbin: address and reference book for 1926]. Kharbin: tip. Kitayskoy vostochnoy zh. d. 